\title{
N. F. S. GRUNDTVIG: RIMBREV TIL LISE
}

(12te Aug. 1835).

Ved Jørgen Fabricius.

I sin udgave af »N. F. S. Grundtvigs Poetiske Skrifter« offentliggjorde Svend Grundtvig ialt ni af faderens digte til Elisabeth Christina Margrethe Blicher, med hvem Grundtvig blev forlovet i september 1811 og ægteviet den 12. august 1818. - Fem af disse ni digte er ifølge Svend Grundtvigs oplysninger tilegnelsesdigte, som Grundtvig indskrev i bøger, han forærede sin forlovede. Tre andre af digtene er forfattet $i$ anledning af 》Lises « fodselsdag den 28. september $\mathrm{i}$ årene 1815,1825 og 1828 , og endelig er eet fremkommet ved deres fem års bryllupsdag i 1823. - Medens dette sidstnævnte digt, »Hil dig, kjære Drenge-Moder!«, hidtil har været det eneste kendte skrevet til markering af bryllupsdagen, og et digt skrevet 1829 under den første Englands-rejse (»Ensom i den store Vrimmel«) det overhovedet seneste kendte digt til »Lise« fra Grundtvigs hånd, vil det lille Rimbrev, hvis tekst her fremlægges, forrykke disse forhold.

Rimbrevet til Lise er skrevet $\mathbf{i}$ anledning af bryllupsdagen og - så sent som i 1835. - Den sommer havde Grundtvig lejet »en Huus-Ende《 ikke langt fra »Emilie-Kilde«. »Derude nynner jeg paa de gamle Psalmer, og de klinge, deilig i mit Øre med det blaa Hav og den blaa Himmel for Øie« skriver han den 24. juli til vennen Gunni Busck, hvis rundhåndede understøttelse ikke blot satte Grundtvig i stand til for alvor at arbejde med »Psalmesagen«, men også hjalp familien gennem den værste fortrykthed, der, som Rimbrevet udtaler, især har bekymret fru Grundtvig meget.

\section{Rimbrev til Lise}

(12te Aug. 1835).

Sytten Aar

Er ei som sytten Dage,

Som i Gaar

Jeg tænker dog tilbage

Togange sytten Aar saa næsten

(Men et og tredive for Resten) ${ }^{1}$ )

Til Ungdoms-Tiden, da det lød

Fra hendes Læber, som, skiøndt død,

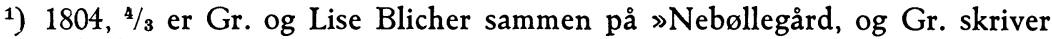
i dagbogen 1804: „Hun er Mig næsten nu, hvad hendes ældste Syster var Mig fordum d:e: Jeg kender ingen Pige, som Jeg lider beder end hende . ... (H. Begtrup: N. F. S. Grundtvigs udvalgte Værker, I, pag. 50 (Kbh. 1904)). 
Dog taler med i mangt et Bryst,

som mindes Blik og Røst;

Det lød om Huset') bag de grønne Høie,

Og om »min Lises《 milde $\varnothing_{\text {je. }}$

Stod hun iblandt os med det muntre Blik,

Saa frisk som daglig det med Soel opgik,

Og hilste hun $\mathrm{i}$ venlig Iil

Dig med sit Morgenrøde-Smil,

Paa denne Soelskins-Dag,

Hvor under lave Tag

Paa Sundets Bredd opstiger Røgen

I Vift fra Bøgen,

$\mathrm{Da}$ aanded hun i sit God-Morgen »ad fare Sorgen «!

Saa mildt at vist med Iil

Sig Taaren klared til et Smil!

Skiøndt Sanger jeg vel fordum hedd,

Jeg kan ei synge, som $D u$ veed,

Og selv naar det er mildt forinden

Mit Udtryk ligner Norden-Vinden, //

Og Ynde fremfor Alt omsonst

Man eftergiør med Konst,

Saa det »God-Morgen « jeg dig ønsked sagt

Med hele Stemmens Trylle-Magt

Kan jeg kun stamme ud heel stivt

Og vrævle om i Skrift,

Og hvad jeg kan lidt bedre med,

Det passer ei til Tid og Sted,

Som $\mathrm{i}$ det Hele kun paa Strid

Jeg passer til min Tid,

Som, lod det gamle Ord kun gaae,

Som Nave knyt til Øine blaa.

Det bedste Raad, jeg med min Pen

kan give til min bedste Ven

Er og det bedste, jeg kan finde

Til Dig, min kiæreste Veninde,

Skiøndt Ulligheden godt jeg seer

Imellem Kampe-Steen og Leer,

Det Raad som giennem mange Aar

Vel ei har frelst mit gule Haar,

Der tvertimod blev tidlig graat

Men har dog ellers hjulpet godt,

Saa, trods fuldmangen Preen og Piil,

Jeg har til Verden end et Smil

Saa Raadet er al Fre værd:

Tag ikke Verden Dig for nær,

Og regn til Verden hele Summen

Af egen Piben og af Andres Brummen,

2) Gunslev præstegård, Lises barndomshjem, hvor faderen, Didrik Nicolai Blicher var præst fra 1781 til 1805. Det er hans hustru, Mette Poulsen (1751-1826), Gr. fremkalder mindet om i disse linier. 
Hver Draabe af den Humle-Urt,

Der giør ei Ansigt blot men Livet surt!

Jeg ved det nok, det kniber her,

Med Pengene især //

Den Lande-Plage paa vor Jord

Fra Syd til Nord,

Men dog den Tanke hjalp mig tit

At af det Onde har Man ei forlidt,

Og Fattig-Folk har Lidt at dele

Imens de Rige har det Hele

Og har, til allerstørst Fortræd, Sædvanlig 》Roden « med.

Den haaber jeg vi ikke har,

Skiøndt der blev tit en Penge-Nar

Af hvem der, mens han havde Ingen,

kun narredes med Tingen,

Og naar Man kun er fri for Roden

Til alt Ukrudt paa Kloden,

Med Blad og Blomst og Frugt,

Skiøndt slemme nok, Man faaer vel Bugt,

Thi hvad der saa kan hænde,

Det faaer dog Ende

Vist nok igien

Det tit var Klagen den,

At Pengene, som let kan hænde,

For snart fik Ende,

Men Mammon selv kan dog forstaae,

At hver en Penge-Sorg er liden

Mod den, der voxer kun med Tiden

Og bliver aldrig Ende paa!

Dog, Nok om Pengene! og hvad for Resten

Deels for sig selv og deels for Næsten

Man ei maa tage sig for nær //

Jeg ikke vil opregne her,

Men heller pege ud paa Sundet,

Der ikkun har saa længe rundet

Og har sit Smil end ei forgixt,

Fordi det tog sig Alting let,

Tog Stormene fra Syd og Nord

Som al den Sne, der faldt i Fjor

Tog ei for nær sig Vaaben-Braget

Skiøndt rystet i Skiærthorsdags Slaget ${ }^{3}$ ),

Lod alle Kiøle, selv med stjaalne Vahre,

Kort sagt, lod Alting »overfare «!

Gid Det, som her vi har for Øie,

Maa baade »nytte og fornøie«,

Hvortil i hele Verden knapt

Et lille Sund er bedre skabt

3) Slaget på reden den 2. april 1801. 
End Øre-Sund i Dane-Vangen

Der minder blidt om Helte-Sangen

Og lader ofte Bølgen trille

Saa smukt som for at spille

Med Harpe-Slag af Voven

Til Sang i Bøge-Skoven!

Dog først og sidst jeg peger did

Hvor over Bjerg som over Mid

Og over Hav som over Sund

Sig hvælver Buen dyb og rund, Thi der jeg seer en Haand udrakt Med Fader-Blik og Guddoms-Magt, Hvori det er alt Støvets Held At lægge trygt sit Vee og Vel Med Øiet paa den aabne Favn, Med »Fader vor« i Jesu Navn!

N. F. S. Grundtvig. 